\title{
Gambaran Kepentingan Politik Kelompok Komunis di Indonesia: Pemogokan Buruh di Delanggu 1948
}

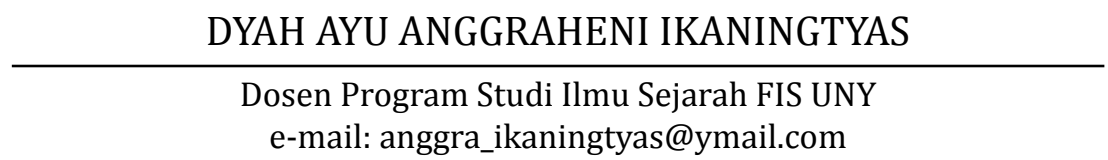

\begin{abstract}
Abstrak
Penelitian ini bertujuan untuk membahas mengenai pemogokan buruh di Delanggu tahun 1948 dan membahas sikap pemerintah dengan adanya pemogokan buruh di Delanggu. Metode penelitian sejarah dengan heuristik, verifikasi, interpretasi, dan penulisan. Sumber penelitian berupa arsip kepolisian koleksi Arsip Nasional Indonesia, Encyclopedie van Nederlansch-Indië, serta buku penunjang. Hasil penelitian menyimpulkan bahwa pemogokan buruh di Delanggu berkaitan dengan adanya pergerakan partai komunis, tidak hanya semata-semata persoalan perut kaum buruh. Kekecewaan kelompok komunis terhadap pemerintah Indonesia, dengan memobilisasi kaum buruh untuk melakukan aksi pemogokan. Aksi ini menambah suasana panas suhu politik kala itu. Pemogokkan di Delanggu menjadikan terbengkalainya perkebunan rosella dan kapas yang mensuplai bahan baku pembuatan karung goni. Gerakan yang ternyata juga bermuatan politik dari komunis ini mengakibatkan kerugian bagi pabrik karung goni tentu saja juga merugikan negara, karena pabrik karung goni Delanggu diambil alih pemerintah RI setelah proklamasi kemerdekaan Indonesia.
\end{abstract}

Kata kunci: Buruh, Pemogokan, Delanggu

\begin{abstract}
This research aims to describe the labors' strike in Delanggu 1948 and the government's responses to the strikes in Delanggu. The method of historical research includes verification, interpretation, and writing. The research sources consist of police records collections of the National Archives of Indonesia, Encyclopedie van Nederlansch-Indie, and other supporting materials. The research findings conclude that labor strikes in Delanggu is related to the movement of the communist party, not merely due to economic problems faced by the labors. The disappointment of the communists group against the Indonesian government is expressesd by mobilizing the labors to strike. This action improved the heat of the political climate at the time. The strike in Delanggu caused the abandonment of rosella and cotton plantations that supply raw material for the sack. The movement that was also covered by politics of the communists group caused damages to sacks factory and the country, because the sacks factory in Delanggu was taken over by Indonesian government after the proclamation of Indonesian independence. Keywords: Labor, strike, Delanggu
\end{abstract}




\section{PENDAHULUAN}

Delanggu merupakan salah satu kecamatan di kabupaten Klaten. Pada mulanya Delanggu merupakan sebuah desa di Jawa Tengah yang masuk dalam karesidenan Surakarta (Amsterdam: PN. Van Kampen, 1861). Pada 1896, Delanggu belum tercatat sebagai sebuah distrik di afdeeling Klaten. Sampai tahun tersebut yang tercatat sebagai distrik di afdeeling Klaten adalah, Klaten, Gesikan, Sapuluh, Prambanan, Gedongan, Kalisongo, Kartosuro, Ketitang, Jenom, Taraman, dan Bendodalem (Amsterdam: Joh. G. Stemler C2, 1896: 13). Sampai akhir abad 19, Delanggu masih berupa sebuah desa, yang kemudian berkembang menjadi onderdistrik bahkan menjadi distrik dengan membawahi empat onderdistrik, yaitu Delanggu, Wonosari, Nrenden, dan Kebongede.

Delanggu memiliki lahan pertanian subur dengan iklim yang baik serta tercukupinya sumber pengairan, dengan ketinggian 153 meter (BPS Klaten, 1986: 11).Tanah pertanian Delanggu termasuk tanah regosol kelabu yang mengandung abu dan pasir vulkanik intermedier,dengan produktifitas sedang sampai tinggi yang cocok untuk pertanian dan perkebunan. Soemartono dan R. Hardjono mengatakan bahwa tanah subur yaitu tanah berhumus yang di dalamnya menyimpan struktur remah serta mengandung udara. (Soemartono Bahrin Samad \& R. Hardjono, 1974: 19).

Jumlah penduduk distrik Delanggu pada akhir tahun 1905, terdapat 44.400 penduduk, di dalamnya termasuk 60 orang Eropa dan dalam jumlah yang sama penduduk Cina. Kedudukan masyarakat Eropa di perkebunan Delanggu menempati posisi atas, kemudian di bawahnya sebagai kontrolir biasanya diduduki orang-orang Cina. Sementara masyarakat Delanggu berada di jabatan paling rendah, sebagai buruh. Pada masa kolonial Belanda, masyarakat Delanggu dimanfaatkan tenaganya untuk bekerja di perkebunan, mulai sebagai buruh tanam, buruh panen, dan buruh angkut, serta juga sebagai pekerja di pabrik gula.

Lokasi Delanggu jika dilihat dari jalur transportasi, merupakan wilayah yang stra- tegis. Menurut Soegijanto Padmo (2004: 9192) Delanggu dilalui jalan utama yang menghubungkan Yogyakarta dengan Surakarta, selain itu distrik Delanggu juga dilintasi jalur kereta api. Pada 1870-an dibangun jalan kereta api yang melewati Klaten, serta dibang un lima stasiun di kabupaten Klaten diantaranya, Prambanan, Srowot, Klaten, Ceper, dan Delanggu.

Menurut Denys Lombard (2010: 139140) pada 1894 jalur lintas Jawa pertama yang menghubungkan Batavia dengan Surabaya melalui Maos, Yogya dan Solo selesai dibangun. Lokasi Delanggu yang dilalui jalur kereta serta jalan utama YogyakartaSurakarta, mempermudah arus distribusi barang hasil produksi maupun perkebunan dari ataupun ke Delanggu.

Pada akhir abad 19, selain sebagai lahan menanam padi, lahan pertanian di Delanggu juga digunakan sebagai perkebunan tebu. Oleh Suhartono (1993: 98) disebutkan bahwa pada 1871 luas perkebunan tebu Delanggu mencapai 404 bau dengan hasil produksinya 16.183 pikul.Meskipun memiliki perkebunan tebu, sampai awal abad 20 belum memiliki pabrik gula, baru pada 1917 di Delanggu dibangun pabrik Gula (Sarjana Sigit Wahyudi, 2001: 118). Sebelum ada pabrik Gula, hasil perkebunan tebu yang ada digunakan untuk memenuhi kebutuhan tebu bagi pabrikpabrik gula di wilayah Kabupaten Klaten.

Masyarakat Jawa Tengah dan sekitarnya ketika mendengar kata Delanggu, dalam memori kolektif mereka akan mengingat bahwa Delanggu adalah penghasil beras yang enak dan pulen. Sampai sekarang pun, Delanggu masih dikenal sebagai penghasil beras berkualitas.

Meskipun pada 2012, Delanggu mengala mi gagal panen, ingatan yang melekat pada masyarakat, tanpa melihat kondisi pertanian Delanggu yang semakin menurun, tetap menganggap bahwa Delanggu adalah penghasil beras bahkan pernah menjadi lumbung padi Kabupaten Klaten.

Berdasarkan penelitian Sajogo dan William L. Collier (1986: 181) pada 1922-1927, hasil produksi padi di distrik Delanggu merupakan yang terbanyak jika dibandingkan 
dengan distrik-distrik lainnya di karesidenan Surakarta, yaitu 33,73 pikul per hektar atau 20,38 kuintal per hektar.

Varietas padi lokal Delanggu yang menjadi andalan dengan memiliki rasa enak dan tekstur pulen yaitu varietas Rojolele. Belum ditemukan data mengenai waktu varietas tersebut mulai ditanam di Delanggu. Namun yang pasti, varietas tersebut merupakan varietas asli dari Delanggu yang telah lama ditanam masyarakat secara turun temurun. Pemberian nama Rojolele oleh masyarakat Delanggu, berkaitan dengan kualitas rasa dari varietas tersebut.

Rasa nasi dari beras Rojolele jika dibandingkan dengan varietas-varietas bulu lain seperti Gadis, Sinta, Bengawan, dan Slogo, memiliki rasa lebih enak (hasil wawancara dengan Bapak Maryanto). Maka masyarakat Delanggu dan sekitarnya menyebut beras Rojolele adalah raja dari varietas-varietas lainnya. Selain itu bentuk fisik Rojolele memiliki dua bulu panjang yang mirip kumis lele,maka varietas lokal Delanggu tersebut disebut Rojolele.

Tanaman padi ini berkembang di Delanggu sehingga menjadikan Delanggu diingat oleh masyarakat sebagai penghasil padi deng an kualitas rasa enak serta tekstur pulen. Selain dikenal dengan berasnya, Delanggu juga dikenal sebagai penghasil karung goni. Sejarah karung goni di Delanggu menarik untuk ditulis, karena tidak hanya berkaitan dengan sejarah ekonomi masyarakat Delanggu dan sekitarnya, tetapi juga berkaitan dengan sejarah sosial masyarakat. Pabrik karung Goni Delanggu yang semula adalah pabrik gula, ternyata juga menyimpan cerita mengenai pemogokan buruh yang memiliki hubungan dengan adanya pergerakan partai komunis di Indonesia pada 1948.

\section{METODE}

Penelitian ini merupakan penelitian sejarah dengan menggunakan metode penelitian antara lain: heuristik, verifikasi, interpretasi, dan penulisan. Sumber-sumber yang digunakan dalam penelitian ini berupa arsip kepolisian koleksi Arsip Nasional Indonesia, Encyclopedie van Nederlansch-Indië, serta buku-buku penunjang lainnya.

\section{HASIL DAN PEMBAHASAN}

\section{Pabrik Gula Delanggu Beralih Fungsi menjadi Pabrik Karung Goni}

Berdasarkan analisis lokasi, perkembangan Delanggu dari desa menjadi distrik berkaitan dengan adanya perkebunan tebu serta pabrik gula. Perubahan ini oleh pemerintah kolonial Belanda bertujuan untuk mempermudah koordinasi perkebunan-perkebunan yang ada di Delanggu dan sekitarnya, sehingga untuk mempermudah pengawasan serta pendataan secara administratif, desa Delanggu serta desa-desa lainnya disatukan dalam onderdistric Delanggu.

Perkebunan tebu di Delanggu memulai adanya perburuhan. Selain itu perkebunan tebu juga menyebabkan perubahan pola tanam padi.Petani yang semula konsisten bertanam padi, dengan adanya perkebunan juga turut ambil bagian menjadi buruh karena berkeinginan memperoleh tambahan pendapatan untuk mencukupi kebutuhan keluarga. Penanaman tebu kurang lebih memerlukan waktu 14 bulan (Werner Röll1983: 120). Sementara itu di Kabupaten Klaten, sewa tanah untuk penanaman tebu dilakukan selama 16 bulan. Sawah-sawah di Klaten disewa untuk perkebunan tebu secara bergili ran. Tanaman tebu yang cenderung memerlukan waktu lebih lama dibandingkan padi, menjadikan rusaknya pola tanam padi. Letak perkebunan tebu biasanya dekat dengan salu ran irigasi.

Menurut Mubyarto(1992: 112) Perkebunan tebu menjadikan penggunaan air diutamakan untuk perkebunan,sementara petani yang masih tetap menanam padi harus sabar mendapat bagian air setelah digunakan untuk perkebunan tebu. Selain irigasi, tanah untuk perkebunan tebu biasanya lebih baik daripada tanah yang ditanami tanaman padi.

Pengambilalihan tanah-tanah pertanian untuk perkebunan melalui sewa mempermudah pemerintah kolonial untuk mendapatkan tenaga kerja. Karena dengan semakin berkurangnya lahan pertanian pangan, menyebabkan petani kekurangan penghasilan 
dari lahannya yang semakin sempit. Oleh karena itu untuk mendapatkan penghasilan selain di tanahnya yang sempit, petani menjadi buruh pabrik atau perkebunan.

Pada masa kolonial, perkebunan tebu Delanggu yang ada sejak 1917 semakin berkembang, ini dibuktikan dengan hasil produksinya dari tahun ke tahun. Adanya perkebunan serta beroperasinya pabrik gula, semakin menambah besar jumlah buruh di Delanggu dan sekitarnya. Seperti di sebutkan di atas, masyarakat Delanggu dan sekitarnya bekerja sebagai buruh, sementara penduduk Eropa khususnya Belanda bekerja sebagai pegawai administratif perkebunan dan pabrik. Sehingga akan terlihat perbedaan kehidupan sosial antara buruh dan pegawai andimistratif.

Perkembangan pabrik gula Delanggu dapat diamati dari hasil produksi dari tahunke tahun. Hasil gula yang dari pabrik tersebut sebagai berikut:

Tabel 1

\section{Hasil Produksi Gula di Pabrik Gula Delanggu}

\begin{tabular}{ll}
\hline Tahun & Produksi \\
\hline 1923 & 164.978 pikul \\
1924 & 171.667 pikul \\
1925 & 168.551 pikul \\
1926 & 143.041 pikul \\
1927 & 201.278 pikul \\
1928 & 204.000 pikul \\
\hline
\end{tabular}

Sumber: Encyclopedie van Nederlansch-Indië Tweede Druk. 1929

Perkembangan pabrik gula di Delanggu mengalami gangguan, karena pada awal tahun 1930-an, pemerintah kolonial Belanda mengalami masa malaiseyang menyebabkan mundurnya perusahaan-perusahaan di Hindia Belanda. Malaise ini mematikan usaha perkebunan di Jawa, terutama produksi gula yang masih hidup pada waktu itu (Clifford Geertz 1984: 24).

Sekitar 84 persen pabrik gula ditutup pada 1932 dan selebihnya menurunkan upah buruh menjadi setengahnya (Eybert de Vries 1985: 87). Buruh pabrik menjadi pihak yang tertekan dengan kondisi tersebut. Pabrik Gula Delanggu juga merasakan dampaknya, penghasilan pabrik gula menurun drastis sehingga pada 1933 pabrik tersebut ditutup. Perkebunan tebu yang terbengkalai kemudian diambil alih oleh masyarakat Delanggu untuk ditanami tanaman pangan.

Pada 1934, Delanggu mulai dilakukan penanaman rosela dan rami untuk pembuatan karung goni.Terdapat enam daerah perkebunan rosela untuk memenuhi kebutuhan serat bagi pabrik karung goni di Delanggu, yaitu Delanggu pusat, Polanharjo, Juwiring, Kedung Bandeng, Gayamprit, dan Manjung. Bangunan pabrik gula Delanggu kemudian difungsikan sebagai pabrik karung goni.

Pabrik tersebut untuk pertama kalinya menghasilkan karung goni yang siap dipa sarkan pada 1938.Rata-rata hasil produksi pabrik tersebut mencapai 5545.000 buah karung goni per tahun.Bahkan, setelah proklamasi kemerdekaan Republik Indonesia, Delanggu menjadi pusat perkebunan rosela Indonesia.

Kondisi sosial masyarakat Delanggu juga dapat dilihat dengan adanya pabrik karung di Delanggu. Keberadaan pabrik dan perkebunan di Delanggu kemudian menunjukkan adanya perbedaan klas, antara buruh dengan tenaga-tenaga administratif pabrik. Mubyarto (1992: 115-116) menyebutkan bahwa dalam perkebunan dan pabrik, orang-orang Belanda berkedudukan sebagai administrator, yaitu suatu jabatan yang berada pada pucuk pimpinan, sementara masyarakat lokal sebagai buruh. Inilah kemudian yang menjadi alasan munculnya konflik akibat perbedaan pendapatan yang mencolok.

Bahkan sampai Indonesia merdeka, serta pabrik Karung Goni Delanggu diambil alih oleh pemerintah Indonesia, ternyata nasib buruh-buruh pabrik serta perkebunan juga tidak jauh berbeda.

Kondisi ini dimanfaatkan oleh kelompokkelompok sosialis dan komunis yang ada di Indonesia untuk memberikan janji-janji membentuk masyarakat makmur.Jika meli- 
hat adanya janji-janji dari kelompok tertentu terlebih lagi partai polotik, khususnya PKI, masalah pemogokan di Delanggu bukan lagi semata-mata berhubungan dengan persoalan ekonomi, tetapi adanya kepentingan politik dari partai tersebut yang memanfaatkan kondisi buruh.

\section{Pemogokan Buruh}

Pasca proklamasi kemerdekaan, kondisi Indonesia belum stabil. Apalagi dengan kembalinya Belanda ke Indonesia untuk me ngambil alih pemerintahan pasca kekalahan Jepang. Belanda merasa berhak atas Indonesia setelah Jepang kalah dalam perang pacifik. Oleh karena itulah Belanda dating kembali lagi ke Indonesia, akan mengambil alih kekuasaan. Tentu saja Pemerintah Indonesia yang telah memproklamasikan kemerdekaan pada 17 Agustus 1945, menolak kedatangan Belanda.

Selain menghadapi kedatangan kembali Belanda, dari dalam diri Indonesia sendiri juga terjadi perselisihan. Menurut Aan Ratmanto (2012: 109) diantara tokoh-tokoh Indonesia terdapat perbedaan ideologi me ngenai mengelola negara yang baru merdeka. Salah satu ideologi yang diinginkan adalah ideologi komunis. Gerakan partai komunis ini lebih terasa ketika Muso kembali lagi ke Indonesia setelah mencari suaka di Uni Soviet karena menjadi buron pemerintah kolonial Belanda.

Kebijakan pemerintah mulai dikritik oleh Muso, karena setelah mencapai kemerdekaan, kondisi Indonesia masih belum stabil. Muso beserta Amir Syaarifuddin, Setiadjit, dan Wikanan aktif berorasi untuk membakar semangat revolusi kepada rakyat. Berikut ini salah satu petikan orasinya menurut Himawan Sutanto (hal 79-80):

"Revolusi Indonesia dalam tiga tahun terakhir ini, tidak begitu berhasil, karena pimpinan kita kaum borjuis. Karena itu kaum proletar harus merebut kepemimpinan apabila revolusi nasional ingin berhasil, apabila PKI memimpin revolusi, keadaan akan kembali normal. Perekonomian yang masih bersifat "aritokratis, keningratan" harus berubah. Perjanjian Linggarjati dan Renville harus di- batalkan dan Republik harus segera menjalin hubungan diplomatic dengan Rusia. Sikap "menjilat" Hatta terhadap Amerika Serikat harus dihentikan, karena ini hanya meng akibatkan bertambahnya bantuan Amerika Serikat terhadap Belanda, dan akan meng akibatkan Indonesia untuk terlibat di dalam kolonialis baru. Karena itu strategi yang tepat untuk menghadapi Belanda adalah "bunuh orang-orang Belanda sebanyak mungkin dan rebut senjatanya. PKI menghormati agama, apabila di dalam sekarang ini, kaum muslim merasa ditindas oleh pemerintah Hatta, seka rang saatnya untuk berjihad fi sabilillah."

Setelah Jepang kalah dan Indonesia memproklamasikan kemerdekaannya, perusahaan karung goni Delanggu diambil alih oleh pemerintah Republik Indonesia, dan pe ngaturannya ditangani oleh Perusahaan Nega ra Perkebunan (PNP) XVII.Terdapat 2.800 pegawai, yang dibedakan menjadi tiga golo ngan yaitu staf administratif, teknisi pabrik dan pengawas.

Ketiga golongan ini merupakan pegawai tetap pabrik. Selain mendapatkan gaji tetap tiap bulan, ketiga golongan ini juga mendapatkan fasilitas lain. Di sekitar pabrik karung goni Delanggu terdapat rumah-rumah yang diperuntukkan bagi pegawai administratif. Bagi tenaga teknisi dan pengawas tidak semua mendapatkan perumahan tetapi diprioritaskan kepada pegawai yang rumahnya jauh dari pabrik. Sementara itu untuk buruh pabrik tidak ada fasilitas lain yang diberikan selain upah kerja mereka.

Perbedaan mencolok antara ketiga golongan tersebut dengan buruh pabrik kemudian dimanfaatkan oleh kelompok kiri, khususnya komunis, untuk memprofokasi untuk melakukan pemogokan. Partai Komunis Indonesia (PKI) untuk menutupi keterlibatannya dalam rencana pemogokan buruh di Delanggu, menjadikan alasan ketimpangan kesejahteraan antara buruh dengan pegawai pabrik yang lain, menggunakan iming-iming kehidupan yang lebih baik dan sejahtera berusaha menarik simpati buruh. Pendapatan buruh pabrik karung goni per bulan berkisar antara Rp. 30 sampai Rp. 45, sementara untuk karyawan staf terendah gajinya 
mencapai Rp. 300 sampai Rp. 400.

Secara politis, karyawan pabrik karung terbagi menjadi tiga golongan utama, yaitu berafiliasi kepada PKI, berafiliasi kepada Masyumi, dan berafiliasi kepada PNI. Antara PKI dan Masyumi tidaklah saling mendukung, dimana Masyumi mendukung peme rintah menentang pemogokan buruh karena dianggap merugikan negara sementara PKI menginginkan adanya revolusi khususnya di Delanggu melalui pemogokkan buruh. Sebagian besar buruh pabrik Delanggu bergabung dalam Sarekat Buruh Perkebunan Republik Indonesia (SARBUPRI), yang mana organisasi ini merupakan organisasi resmi yang mewadahi para buruh. Ternyata perkumpulan ini menanamkan motivasi kepada buruh untuk melakukan pemogokkan untuk memprotes pimpinan pabrik untuk dapat meningkatkan kesejahteraan mereka.

Meskipun sebagian besar buruh di Delanggu baik buruh pabrik maupun perkebunan rosella dan kapas mendukung pemogokkan, tetapi ada juga buruh yang tidak mendukung aksi tersebut. Oleh karena itu, pemogokan mengakibatkan situasi Delanggu tidak aman, sering terjadi kecurigaan antar petani. Di desa Mrisen kecamatan Delanggu pada 27 Juni 1948, sekelompok pemogok mendatangi Prawirosoeharjdo, Partowidjojo dan Kartowihardjo yang dianggap sebagai provokator untuk menentang pemogokan (Arsip Nasional RI No. 1215). Petani yang tetap bekerja di perkebunan rosela, sebagai bahan dasar pembuatan karung goni, diancam akan dibunuh. Petani yang tetap bekerja dianggap tidak memiliki solidaritas akan ketidakadilan terhadap petani dan buruh pabrik yang terjadi di lingkungan pabrik karung goni Delanggu.

Pada dasarnya pemogokan tentu akan merugikan banyak pihak. Petani akan rugi, karena dengan melakukan pemoggokan tentu pendapatan (uang) juga akan terganggu, tetapi yang mengalami kerugian terbesar adalah pabrik karung goni, karena pemoggokan buruh akan mengakibatkan perkebunan rosella terbengkalai sehingga bahan baku pembuatan karung goni tidak tersedia.
Kelompok pemogok di Delanggu tergabung dalam Komite Kesatuan dan Aksi (KKA). Menurut ANRI No. 1215 dalam aksinya, KKA menginstruksikan kepada rakyat Delanggu diantaranya:

1. Menghimbau rakyat agar membantu pemogok,

2. Petani yang tidak mau ikut mogok akan diberi tindakan keras,

3. Dan peristiwa-peristiwa penting yang terjadi di Delanggu harus dilaporkan kepada Komite Kesatuan dan Aksi.

Sementara pemerintah menghimbau kepada masyarakat Delanggu khususnya kepada petani, supaya tidak mudah diperalat karena jika diamati lebih dalam pemogokan buruh di Delanggubukan mengenai kelaparan tetapi juga ada unsur-unsur politik yang melatarbelakanginya.Bukan hanya gera kan bersifat kedaerahan tetapi dikhawatirkan pemogokan di Delanggu merupakan efek dari gerakan nasional yang juga terjadi di beberapa daerah di Indonesia pada 1948.

Pemogokan buruh di Delanggu berlangsung dalam periode yang panjang dan bertahap, yaitu 19 Mei sampai 25 Mei 1948 yang disebut tahap pra pemogokan; $26 \mathrm{Mei}$ sampai 3 Juni 1948 yang disebut tahap awal pemogokan; dan 23 Juni sampai 18 Juli 1948 yang dipandang sebagai tahap penasionalisasian pemogokan buruh Delanggu.

Menurut Sarjana Sigit pada tahap pertama mengorganisasikan demonstrasi di kota solo yang ditangani oleh Sarbupri, diikuti sekitar 5.000 buruh yang didatangkan dari Prambanan, Klaten, Manjung, Gayamprit, Juwiring, Delanggu dan Kedung Banteng. Tuntutan aksi ini mengenai tercukupinya sandang dan pangan. Perlu diingat, pada saat pendudukan Jepang, sandang merupakan barang mahal.

Karung goni dijadikan bahan pakaian, padahal tekstur karung goni yang kasar menyebabkan penyakit kulit, karena karung goni dijadikan bahan pakaian itulah kemudian pemerintah pendudukan Jepang mengeluarkan peraturan tentang pendaftaran karung goni dan larangan menjual, membeli atau memindahkannya.Peraturan ini menunjuk- 
kan betapa berharganya karung goni pada saat itu.

Salah satu isi peraturan tersebut, disebutkan bahwa bagi orang yang memiliki karung goni lebih dari 10, maka ia harus melapor dan mendaftarkannya kepada pemerintah lengkap dengan keterangan untuk apa saja karung tersebut digunakan. Begitu sulitnya kebutuhan sandang dan pangan pada masa pendudukan Jepang, maka pemogokan buruh Delanggu ini menuntut dua hal tersebut.

Namun tutuntan tidak dikabulkan, maka pemogok kembali ke Delanggu dan mempersiapkan aksi yang lebih besar dan tertata. Akhrinya pada 26 Mei 1948, buruh pabrik karung goni Delanggu melakukan pemogokan selama dua jam dengan cara tidak meninggalkan pabrik tetapi hanya diam saja tidak bekerja, pemogokan ini berlanjut pada 27 Mei 1948 sampai 3 Juni 1948. Pemerintah, yang pada saat itu masa cabinet Hatta, mencoba mengkaji lebih mendalam mengenai alasan pemogokan, apakah memang hanya sebatas masalah sosial ekonomi, ataukah sudah sampai pada masalah politik.

Ternyata hasil penelitian tersebut menghasilkan bahwa pemogokan tersebut merupakan persoalan politik. Pemogokan buruh pabrik karung goni Delanggu dapat diselesaikan melalui perundingan, dimana peme rintah memenuhi tuntutan pemogok dengan mempertimbangkan loyalitas buruh kepada pabrik.

Setelah pemoggokan berhenti pada 18 Juli 1948, pemerintah kemudian mengeluarkan peraturan yang membatasi gerak kaum buruh, khususnya untuk mencegak terjadi nya pergerakan yang lebih besar. Menurut Kedaulatan Rakyat, No. 235dalam Sarjana Sigit, hlm. 149-150), Isi peraturan tersebut, yaitu:

a. Menjelaskan posisi buruh dan tugasnya di dalam menghadapi blockade Belanda

b. Larangan untuk melakukan agitasi yang merusak suasana damai yang diusahakan oleh pemerintah

c. Mengidentifikasikan buruh sebagai bagian dari organ Negara, sehingga kepadanya dituntut untuk ikut menye lamatkan Negara

d. Mengidentifikasikan perbuatan buruh yang berlawanan dengan kebijakan negara sebagai perbuatan yang merobohkan begara yang masih dalam keadaan labil

e. Mengingatkan kepada buruh akan wewenang pemerintah untuk me ngambil tindakan terhadap setiap pemogokkan yang mengganggu setabilitas pemerintahan

f. Mengingatkan kewajiban kaum buruh untuk memilih jalan musyawarah di dalam mengatasi setiap persoalan bersama.

Setelah berhentipemogokan tersebut, di Delanggu setiap hari dilakukan patrol dari pihak Mobiele Brigade Kepolisian (MBK). Patro li itu untuk mengamankan Delanggu dari kemungkinan adanya pemoggokan lagi. Setiap hari MBK melaporkan situasi keamanan di Delanggu, yang ternyata relative aman(ANRI. Koleksi Kepolisian Negara. No.342).Diharapkan pemogokan buruh di Delanggu tidak terjadi lagi, karena pemogokan dapat merugikan pabrik-pabrik dari pemerintah. Pemogokan dapat dihindari seandainya adanya kepedulian pimpinan pabrik terhadap nasib buruh, sehingga tidak terjadi pemanfaatan situasi dari kelompok-kelompok politik yang bertujuan menggulingkan pemerintahan.

Sementara itu, setelah pemogokan buruh di Delanggu dapat diatasi, rencana gerakan PKI juga mendapat pengawasan ketat dari pemerintah. Pada 18 September 1948 diproklamasikan Soviet Republik Indonesia di Madiun oleh Kolonel Sumarsono. Pada saat diproklamasikan Soviet Republik Indonesia, Amir Syarifuddin dan Muso sedang berada di Bojonegoro, kemudian setelah mendengar proklamasi terebut keduanya menuju Madiun. Sehari setelah proklamasi tersebut, Presiden Soekarno menyampaikan pidatonya, berbunyi:

"Kemarin pagi PKI-Muso mengadakan coup, mengadakan perampasan di Madiun dan mendirikan di sana pemerintahan 
Soviet di bawah pimpinan Muso. Perampasan ini mereka pandang sebagai permulaan untuk merebut seluruh pemerintahan Indonesia. Njata dengan ini bahwa peristiwa Solo dan Madiun tidak berdiri sendiri melainkan suatu rangkaian tindakan untuk merobohkan pemerintah RI. Buat itu digunakan kesatuan dari Brigade 29, bekas lascar rakyat di bawah pimpinan Letnan Kolonel Dahlan. Selain itu Dahlan telah berkhianat dan melanggar sumpah tentara.

Atas perjuangan untuk Indonesia aku berseru padamu! Pada saat yang begini genting, di mana engkau dan kita meng alami percobaan yang sebesar-besarnya dalam menentukan nasib kita sendiri, dan adalah memilih satu diantara dua:

Ikut Muso dengan PKI-nya, atau ikut Soekarno-Hatta yang InsyaAllah dengan bantuan Tuhan akan memimpin negara Republik Indonesia yang merdeka, tidak dijajah oleh Negara apapun juga..."

Sementara itu pada bulan September 1948, Pasukan Siliwangi (TNI) melakukan pengejaran terhadap pimpinan-pimpinan PKI. Pasukan Siliwangi yang akan melakukan pengejaran ke Madiun sebelumnya berkumpul di markas staf Brigade 13/Balai Kota Solo.

Rute yang akan dilalui pasukan ini adalah Surakarta-Karanganyar, Tawangmangu, Sarangan, Plaosan, Magetan, Maospati, dan Madiun. Pengejaran sampai ke Madiun itu berhasil merebut kota Madiun dari PKI. Pasukan Siliwangi kemudian bermarkas di Karesidenan Madiun.

Dalam pengejaran ini juga, pada 31 oktober 1948, Muso tewas.Kematian Muso, selaku pimpinan PKI menyebabkan pergerakan partai ini meredup, setidaknya untuk sementara. Maksudnya sementara adalah sewaktuwaktu kelompok komunis bisa saja muncul kembali ketika ketidakadilan bagi masyarakat tidak merata.

Komunis akan memanfaatkan ketidakberdayaan masyarakat yang tidak mampu berbuat apa-apa untuk melawan pemerin- tah, untuk bergabung dan kemudian melakukan gerakan. Meskipun bisa jadi kelompok komunis-sosialis akan muncul dengan baju yang berbeda.

\section{SIMPULAN}

Pemogokkan buruh di Delanggu merupakan peristiwa lokal yang ternyata berkaitan dengan peristiwa nasional. Para buruh yang merupakan warga mayoritas di Kawedanan Delanggu dan sekitarnya, menjadi sasaran strategis bagi partai komunis untuk mencari dukungan melancarkan aksinya melawan pemerintah. Kondisi buruh yang mudah dipengaruhi oleh partai komunis karena adanya provokasi kesenjangan sosial antara pegawai pabrik dengan buruh pabrik dan perkebunan. Pemogokkan ini kemudian tidak hanya mengenai persoalan kesejahte raan buruh saja, tetapi adanya kelompok komunis yang bergerak di Delanggu melalui SARBUPRI, menunjukkan bahwa kepenti ngan politik juga melatarbelakangi pemogokan ini.

Pemerintah berusaha menghentikan aksi ini melalui himbauan-himbauan untuk waspada adanya provokasi dari partai-partai kiri. Pemogokkan tentu merugikan peme rintah, karena pabrik karung di Delanggu merupakan milik pemerintah. Perkebunan rosella di Delanggu dan sekitarnya, sebagai pemasok serat yang merupakan bahan baku membuat karung goni, menjadi terbengkalai dengan adanya pemogokkan buruh. Terdapat ketakutan dari buruh dan petani yang akan bekerja diperkebunan rosella, karena adanya ancaman dari pihak-pihak yang pro dengan pemogokkan buruh. Pemerintah melalui Mobiele Brigade Kepolisian (MBK) dan TNI, berjaga-jaga mengamankan aksi buruh.

Sementara itu di Tingkat nasional, pengejaran terhadap pimpinan-pimpinan PKI yang berpusat di Madiun dilakukan oleh TNI dan berhasil dengan tertangkapnya Amir Syarifuddin, Suripno, Haryono, Jendral Mayor Jokosuyono, Fransisco Fangiday, Saryono, dan Maruto Darusman serta terbunuhnya Muso dalam pengejaran.UsahaPKI melawan pemerintah baik secara nasional maupun di 
tingkat lokal Delanggu dapat digagalkan.

\section{UCAPAN TERIMA KASIH}

Kami ucapkan terima kasih kepada semua pihak yang turut membantu penelitian ini sehingga dapat diwujudkan dalam bentuk artikel ilmiah. Selanjutnya tidak lupa kami juga menyampaikan terima kasih kepada redaktur jurnal yang dapat memuat hasil penelitian ini sehingga dapat memberikan kontribusi pada perkembangan keilmuan.

\section{DAFTAR PUSTAKA}

ANRI. Koleksi Kepolisian Negara. No.1215.

Aan Ratmanto. 2012. Pasukan Siliwangi, Loyalitas, Patriotisme dan Patriotisme. Yogyakarta: Matapadi Presindo.

Aardrijkskundig en Statistisch Wordenboek Nederlandsch Indie, Eerste deel. A.J. Amsterdam: PN. Van Kampen. 1861.

BPS. 1986. Klaten dalam Angka 1986. Klaten: BPS Klaten.

Encyclopedie van Nederlansch-Indië Tweede Druk. 1917. Met medewerking van verschillende geleerden Ambtenaren en officieren Samengesteld door Mr. Dr. J. Paulus, Oud N.I. Hoofdambtenaar. Eerste deel, A-G.

Geertz, Clifford. 1983. Involusi Pertanian, Proses Perubahan Ekologi di Indonesia.
Jakarta: Bhratara Karya Aksara.

Himawan Sutanto. tt. Madiun dari Republik ke Republik. Jakarta: Kata.

Lombard, Denys. Nusa Jawa: Silang Budaya, Batas-batas Pembaratan. Jakarta: Gramedia Pustaka Utama. 2010.

Mubyarto dkk. 1992. Tanah dan Tenaga Kerja, Kajian Sosial Ekonomi. Yogyakarta: Aditya Media.

Sajogo dan William L.Collier. 1986. Budidaya Padi di Jawa. Jakarta: Obor dan Gramedia.

Sarjana Sigit Wahyudi. 2001. Ketika Sarbupri Mengguncang Pabrik Karung Delanggu 1948 Sebuah Studi Awal dari Pemberontakan PKI Madiun. Semarang: Aini.

Soegijanto Padmo. 2004. Bunga Rampai Sejarah Sosial Ekonomi Indonesia. Yogyakarta: Aditya Media bekerjasama dengan jurusan Sejarah Fakultas Ilmu Budaya UGM dan Program Studi Sejarah Program Pasca Sarjana.

Soemartono Bahrin Samad dan R. Hardjono. 1974. Bercocok Tanam Padi. Jakarta: CV Yasaguna.

Verbeek en Fennema. 1896. Geologische Beschrijving van Java en Madoera, Deel I. Amsterdam: Joh. G. Stemler C2.

Werner Röll. 1983. Struktur Pemilikan Tanah, Studi Kasus Daerah Surakarta-Jateng. Jakarta: CV. Rajawali. 